This work is licensed under a Creative Commons Attribution License (CC BY 4.0).

\author{
Research article
}

urn:1sid:zoobank.org:pub:A920AF4E-6A95-4109-A403-6A93BD444222

\title{
Three new species and new records of the genus Centromerus (Araneae, Linyphiidae) from Italy
}

\author{
Francesco BALLARIN ${ }^{1, *} \&$ Paolo PANTINI ${ }^{2}$ \\ ${ }^{1}$ Systematic Zoology Laboratory, Department of Biological Sciences, Tokyo Metropolitan University, \\ 1-1 Minami-Osawa, Hachioji-shi, 192-0397, Tokyo, Japan. \\ ${ }^{1}$ Department of Zoology, Museo Civico di Storia Naturale of Verona, \\ Lungadige Porta Vittoria 9, 37129, Verona, Italy. \\ ${ }^{2}$ Museo Civico di Scienze Naturali “E. Caffi” of Bergamo, Piazza Cittadella 10, 24129, Bergamo, Italy. \\ *Corresponding author: ballarin.francesco@gmail.com \\ ${ }^{2}$ Email: ppantini@comune.bg.it \\ ${ }^{1}$ urn:1sid:zoobank.org:author:54F6F9C7-0385-48D4-AB09-52692BD05B53 \\ ${ }^{2}$ urn:lsid:zoobank.org:author:0DBEC88D-5BF7-47BA-A095-C292078E794D
}

\begin{abstract}
Three new species of the genus Centromerus from Italy, $C$. tongiorgii sp. nov., $C$. hanseni sp. nov., and C. gatoi sp. nov., are described for the first time on the basis of both male and female specimens. Their relationships with other congeneric species, as well as their diagnoses, are discussed using morphological characters. New records of poorly known species of Centromerus from Italy are furthermore reported. Among them, $C$. desmeti Bosmans, 1986 is reported for the first time for the Italian fauna and for continental Europe.
\end{abstract}

Keywords. Apennines, Calabria, endemic species, Italian peninsula, new data.

Ballarin F. \& Pantini P. 2020. Three new species and new records of the genus Centromerus (Araneae, Linyphiidae) from Italy. European Journal of Taxonomy 660: 1-23. https://doi.org/10.5852/ejt.2020.660

\section{Introduction}

Centromerus Dahl, 1886 is a genus in the family Linyphiidae Blackwall, 1859 distributed in the Palaearctic and Nearctic realms. It currently includes 87 species/subspecies (WSC, 2020), 65 of which are present in Europe (Nentwig et al. 2020). Along the Italian Peninsula, 23 species of Centromerus are currently known: C. arcanus (O. Pickard-Cambridge, 1873), C. bonaeviae Brignoli, 1979, C. brevipalpus (Menge, 1866), C. capucinus (Simon, 1884), C. cavernarum (L. Koch, 1872), C. cottarellii Brignoli, 1979, C. incilium (L. Koch, 1881), C. isaiai Bosmans, 2015, C. leruthi Fage, 1933, C. levitarsis (Simon, 1884), C. marciai Bosmans \& Gasparo, 2015, C. pabulator (O. Pickard-Cambridge, 1875), C. pasquinii Brignoli, 1971, C. puddui Brignoli, 1979, C. satyrus (Simon, 1884), C. sellarius (Simon, 1884), C. semiater (L. Koch, 1879), C. serratus (O. Pickard-Cambridge, 1875), C. silvicola (Kulczyński, 1887), C. subalpinus Lessert, 1907, C. subcaecus Kulczyński, 1914, C. succinus (Simon, 1884) and C. sylvaticus (Blackwall, 1841). In addition, three more species are recorded, but considered dubious 
or species inquirendae: C. paradoxus (Simon, 1884), C. prudens (O. Pickard-Cambridge, 1873) and C. tridentinus di Caporiacco, 1952 (Pantini \& Isaia 2019).

With the exception of a few widespread and locally abundant species, the Italian fauna of Centromerus is generally poorly known. The taxonomy, ecology and distribution of species of Centromerus are still unsatisfactory, often being based on a few old records. Studying linyphiid material collected in various localities in Italy, we had the opportunity to examine several specimens of Centromerus of both sexes. New records of some rare and poorly known species were found. In addition, a detailed morphological analysis of male and female specimens led to the discovery of three unknown species. The aim of this work is to describe these new species and to improve our knowledge of the Italian fauna of Centromerus by reporting new records and new localities of poorly known species.

\section{Material and methods}

Specimens were collected, using pitfall traps or sieving through leaf litter, and fixed in $75 \%$ ethanol for morphological studies. Photographs and measurements were taken at the Systematic Zoology Laboratory, Tokyo Metropolitan University, Japan, using a Canon EOS 60D digital camera mounted on a Nikon SMZ 1270 stereo microscope. Epigynes and vulvae of small specimens were photographed using the same camera mounted on a Nikon Optiphot 2 microscope. Final images were merged using Helicon Focus 6 image stacking software. The left palps of males are illustrated. To study internal structures of female genitalia, epigynes were removed and boiled for 5-6 minutes in a $20 \% \mathrm{KOH}$ solution. Leg measurements are reported as follows: femur, patella, tibia, metatarsus, tarsus (total length). All measurements are in millimeters. The specimens examined in this study are stored in the Museo Civico di Scienze Naturali "E. Caff”" of Bergamo (MSNB), Museo Civico di Storia Naturale of Verona (MSNV), Museu de Ciències Naturals of Barcelona (MCNB), Muséum d'Histoire naturelle de la Ville de Genève (MHGN) and Natsionalen Prirodonauchen Muzey of Sofia (NMNS).

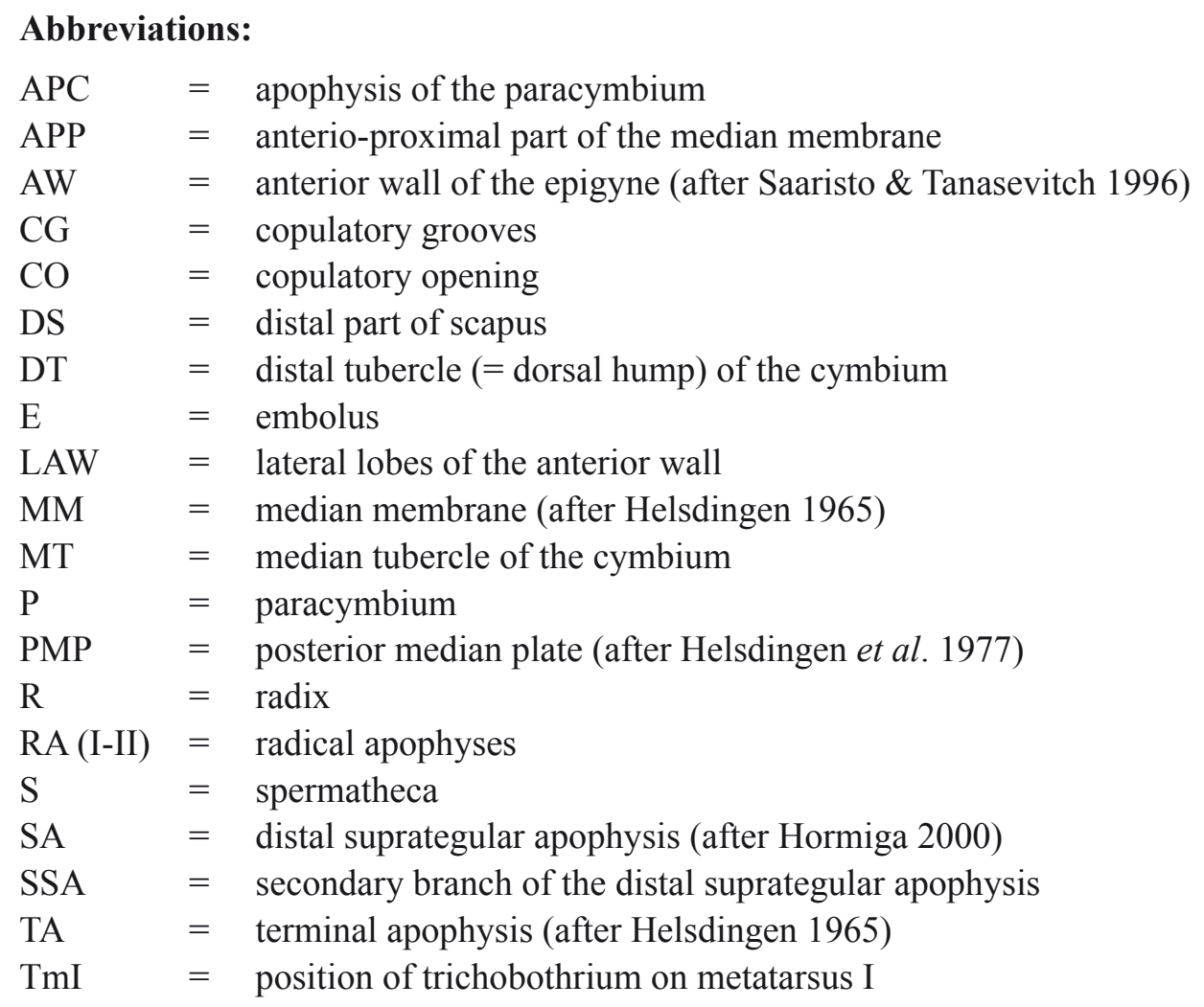




\title{
Results
}

\author{
Class Arachnida Cuvier, 1812 \\ Order Araneae Clerck, 1757 \\ Family Linyphiidae Blackwall,1859 \\ Subfamily Micronetinae Hull, 1920 \\ Genus Centromerus Dahl, 1886
}

\section{Type species}

Centromerus brevipalpus (Menge, 1866).

Centromerus tongiorgii sp. nov. urn:1sid:zoobank.org:act:19C54F31-6D19-4624-8A63-82FA97B9E620

Figs $1-2,10$

\section{Diagnosis}

The new species is morphologically closely related to Centromerus isaiai, C. hanseni sp. nov. and C. sylvaticus. Male C. tongiorgii sp. nov. can be distinguished from male $C$. isaiai by the slimmer, thread-like second radical apophysis (RA-II), which appear thicker and sturdier in the latter species, and by the larger, more rounded median tubercle of the cymbium (MT) which is smaller and more pointed in C. isaiai (Figs 1A-B, 2A-C vs Bosmans \& Colombo 2015: figs 4-6, 10). Males of the new species are separated from male $C$. hanseni sp. nov. by the triangular shape of the dorsal hump (DT), which appears flatter and more squared in $C$. hanseni sp. nov., and by the presence of a median tubercle (MT), lacking in $C$. hanseni sp. nov. (Figs 1A-B, 2A-B vs Figs 3A-B, 4A-B). In addition, the two species can be separated by the shorter and poorly visible radical apophysis I (RA-I) in C. tongiorgii sp. nov., which is always clearly visible in $C$. hanseni sp. nov. when the palp is observed prolaterally or retrolaterally, and by the lack of any apophysis on the distal part of the paracymbium (APC), present instead in C. hanseni sp. nov. (Figs 1A-C, 2A-C vs Figs 3A-C, 4A-C). Male C. tongiorgii sp. nov. can easily be distinguished from male $C$. sylvaticus by the smaller size (1.69-2.25 vs 2.2-4.0), by the lack of teeth on the lateral margin of the paracymbium (P), which is armed with teeth in C. sylvaticus, and by the slimmer and more curved radical apophysis II (RA-II) in contrast to the thicker and straighter RA-II in C. sylvaticus (see Figs 1A, 2A vs Roberts 1987: fig. 64a). Females of the new species are separated from those of $C$. isaiai and C. sylvaticus by the shorter anterior wall (AW) with a wider base and ending with a sharp point, instead of a long lobe as in the latter two species (see Figs 1E, 2D vs Bosmans \& Colombo 2015: figs 7, 8, 12 and Roberts 1987: fig. 64a). The different shape of the posterior median plate (PMP) further distinguishes these species, as the PMP is rectangular in $C$. tongiorgii sp. nov., in contrast with a squared PMP in C. hanseni sp. nov., a triangular PMP in C. isaiai and a trapezoid PMP in C. sylvaticus (see Figs 1G, 2E vs Fig. 3G, E vs Bosmans \& Colombo 2015: fig. 13 and Wiehle 1956: fig. 55). In addition, female $C$. tongiorgii sp. nov. are easily distinguished from female $C$. sylvaticus by their smaller size (1.8-2.1 vs 3.5-4). Female $C$. tongiorgii sp. nov. are distinguished from female $C$. hanseni sp. nov. by the sharp tip of the anterior wall (AW), lacking a truncated ending as in $C$. hanseni sp. nov., and by the narrower posterior median plate (PMP), which is larger in $C$. hanseni sp. nov. (Figs 1E, G, 2D-E vs Figs 3E, G, 4D-E).

\section{Etymology}

The specific name is a patronym in honour of Prof. Paolo Tongiorgi, a well-known Italian zoologist who passed away in 2018. Tongiorgi extensively contributed to the study of the taxonomy and biology of European spiders of the family Lycosidae. 


\section{Material examined}

\section{Holotype}

ITALY - ${ }^{7}$; Veneto Region, Verona, Negrar, Val Borago, SW of Montecchio village; $\sim 45.5188^{\circ} \mathrm{N}$, $10.9816^{\circ}$ E; 463 m a.s.1.; 8 Jan.-12 Feb. 2004; submesophilic meadow and common hornbeam (Carpinus betulus) deciduous forest, in the litter; pitfall traps; L. Reich leg.; MSNV.

\section{Paratypes}

ITALY - Veneto Region • 2 ô; same collection data as for holotype; 12 Feb.-18 Mar. 2004; L. Reich leg.; MSNV • 1 今 ; Verona, Grezzana, Val Galina, Le Volpare; $45.5229^{\circ} \mathrm{N}, 10.9916^{\circ} \mathrm{E} ; 520 \mathrm{~m}$ a.s.1.; 28 Nov. 2003-8 Jan. 2004; submesophilic meadow, in the litter; pitfall traps; L. Reich leg.; MSNB • 1 万, 2 우; same locality as for preceding; 8 Jan.-12 Feb. 2004; L. Reich leg.; MSNB • $2 \widehat{\partial} \widehat{\partial}, 1$ q; same locality as for preceding; 12 Feb.-18 Mar. 2004; L. Reich leg.; MSNV • 1 , 1 क; same locality as for preceding; 18 Mar.-28 Apr. 2004; L. Reich leg.; MSNB.

\section{Other material}

ITALY - Lombardia Region • $4 \hat{\partial} \widehat{\partial}, 1$ ; Bergamo, Endine Gaiano, Lago di Gaiano; $340 \mathrm{~m}$ a.s.l.; 2 Apr.-9 May 1996; pitfall traps; P. Pantini leg.; MSNB - 1 क ; Bergamo, Solto Collina, San Defendente; 670 m a.s.1.; 9 May-19 Jun. 1996; pitfall traps; P. Pantini leg.; MSNB. - Liguria Region • 1 ô; La Spezia, Varese Ligure, Passo Cento Croci; 1000 m a.s.l.; Sep. 1991-May 1992; pitfall traps; G. Buttarelli, R. Cerbino, P. Pantini and M. Valle leg.; MSNB. - Veneto Region - 1 गे; Padova, Teolo, Monte Venda; 450 m a.s.l.; 8 Oct. 2002-27 Mar. 2003; Castanea sativa wood; pitfall traps; Museo BG staff leg.; MSNB - 5 우 우 ; Verona, Custoza, along Valle Molini road; $45.3727^{\circ} \mathrm{N}, 10.7909^{\circ} \mathrm{E} ; 120$ m a.s.1.; 29 Mar. 2010; in the litter; sieving; A. Sette leg.; MSNV • 1 \%; Verona, Grezzana, Case Vecie; $45.5243^{\circ} \mathrm{N}, 10.9989^{\circ} \mathrm{E}$;

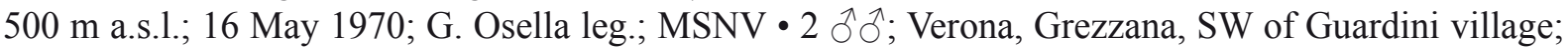
$250 \mathrm{~m}$ a.s.1.; 12 Feb.-18 Mar. 2004; uncultivated meadow with sparse arboreal vegetation, in the litter; pitfall traps; L. Reich leg.; MSNV • 1 क; Verona, Grezzana, Val Galina, Spigolo; 290 m a.s.l.; 18 Mar.28 Apr. 2004; dry meadow, in the litter; pitfall traps; L. Reich leg.; MSNB • 1 ; ; Verona, Grezzana, Val Galina, Vajo dei Casotti; 500 m a.s.1.; 28 Nov. 2003-8 Jan. 2004; deciduous forest; pitfall traps; L. Reich leg.; MSNB • 1 §; Verona, Grezzana, Val Galina, W of the "Cave di Pietra" locality; $175 \mathrm{~m}$ a.s.1.; 12 Feb.-18 Mar. 2004; mixed forest, in the litter; pitfall traps; L. Reich leg.; MSNV • 1 o , 3 o o ; Verona, Illasi, park of Villa Sagramoso Perez Pompei; $45.4703^{\circ}$ N, $11.1865^{\circ}$ E; $195 \mathrm{~m}$ a.s.1.; 7 Apr. 2010; in the litter; sieving; A. Sette leg.; MSNV • 1 ○े, 4 우; same locality as for preceding; $45.4683^{\circ} \mathrm{N}, 11.1904^{\circ} \mathrm{E}$; 230 m a.s.1.; 6 Mar. 2010; sieving; A. Sette leg.; MSNV • 1 q; Verona, Velo Veronese, Camposilvano, outside the Covolo di Camposilvano cave; $1180 \mathrm{~m}$ a.s.1.; $45.6256^{\circ} \mathrm{N}, 11.0911^{\circ} \mathrm{E}$; $30 \mathrm{Aug}$. 2018; in the litter of a deciduous wood, sieving; F. Ballarin leg.; MSNV • 1 సं; Vicenza, Castelgomberto; $300 \mathrm{~m}$ a.s.1.; 8 Oct. 2002-27 Mar. 2003; Castanea sativa wood; pitfall traps; Museo BG staff leg.; MSNB - 1 +; Vicenza, Montecchio Maggiore; 87 m a.s.1.; 2-8 Apr. 2018; forest; pitfall traps; D. Nardi leg.; MSNB • 1 ठ̊; Vicenza, Montecchio Maggiore, Monte Nero; $4-14$ Feb. 2019; pitfall traps; D. Nardi leg.; MSNB - 1 +; Vicenza, Schio, San Rocco; 650 m a.s.1.; 8 Oct. 2002-27 Mar. 2003; beechwood; pitfall traps; Museo BG staff leg.; MSNB. - Emilia-Romagna Region • 19 $\widehat{\jmath}$; Piacenza, Bobbio, near Passo Penice; 1100 m a.s.1.; 19 Sep. 2001-20 Mar. 2002; forest; pitfall traps; P. Pantini leg.; MSNB • 8 ठぇ,

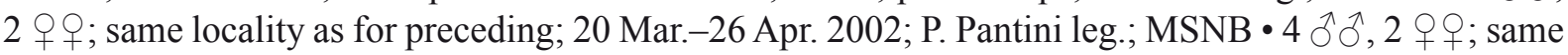
locality as for preceding; 26 Apr.-27 Jun. 2002; P. Pantini leg.; MSNB. - Lazio Region • 1 क; Roma, Canale Monterano, Guallo; 179 m a.s.1.; 16 Mar.-18 Apr. 2007; in the litter; pitfall traps; V. Rizzo and A. Vigna Taglianti leg.; MSNV • 1 đ̊; same locality as for preceding; 15 Jan.-15 Feb. 2008; V. Rizzo and A. Vigna Taglianti leg.; MSNV • 1 §’; Roma, Canale Monterano, Mola Ceccarelli; 250 m a.s.1.; 14 Dec. 2007-15 Jan. 2008; beechwood, in the litter; pitfall traps; V. Rizzo and A. Vigna Taglianti leg.; MSNV - 1 §; same locality; 15 Jan.-15 Feb. 2008; V. Rizzo and A. Vigna Taglianti leg.; MSNV • 1 ○, 1 O; Roma, Canale Monterano, Regional Natural Reserve of Monterano, Diosilla; $42.1313^{\circ} \mathrm{N}, 12.0902^{\circ} \mathrm{E}$; 255 m a.s.l.; 15 Jan.-15 Feb. 2008; deciduous forest with black alder (Alnus glutinosa) and hornbeam 
(Carpinus betulus), in the litter; pitfall traps; V. Rizzo and A. Vigna Taglianti leg.; MSNV. - Marche Region - 1 \&; Macerata, Visso, Monte La Bandita; 1350 m a.s.l.; Jun.-Sep. 1992; pitfall traps; P. Pantini and M. Valle leg.; MSNB. - Umbria Region - 2 q $\circ$; Perugia, San Giustino, Parnacciano; 700 m a.s.l.; Jun.-Dec. 1991; pitfall traps; G. Buttarelli, E. Ghilardi, P. Pantini and M. Valle leg.; MSNB • 1 ð; Perugia, Sigillo, near the village; $550 \mathrm{~m}$ a.s.l.; Jan.-Jun. 1991; pitfall traps; P. Pantini and M. Valle leg.; MSNB • 1 ô, 1 क; Perugia, Sigillo, near Monte Cucco; 850 m a.s.l.; Jan.-Jun. 1992; pitfall traps; P.

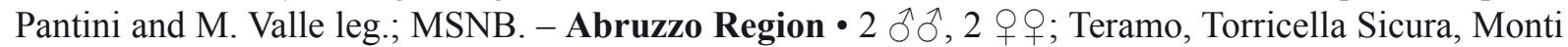
della Laga, $1 \mathrm{~km}$ from Santo Stefano village heading to Rocca Santa Maria; 7 Nov. 2002; O. Marotta

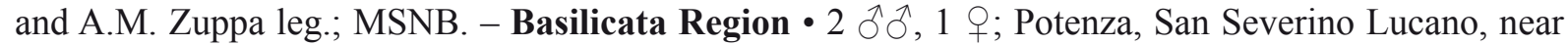
Santuario; 1500 m a.s.l.; Jun. 1990-Jun. 1991; pitfall traps; G. Buttarelli, E. Ghilardi, P. Pantini and M. Valle leg.; MSNB.

\section{Description}

Male

Habitus. See Fig. $1 \mathrm{H}$.

Measurements. Total length 1.69-2.25. Carapace 1.01 long, 0.78 wide.

Prosoma. Carapace uniformly yellowish-brown; chelicerae, labium and gnathocoxae of the same colour. Chelicera with stridulatory ridges on the lateral margin. Three teeth at the anterior margin of the fang groove, posterior margin with 4-5 small denticles. Sternum greyish. Paler, yellowish coloration in some specimens.

ABDOMEN. Covered with sparse setae, uniformly greyish with lighter marks barely visible on the dorsal side, distal end with a lighter area.

Legs. Uniformly yellowish-brown. Femur I with 1 prolateral spine. Tibial spine formula: 2221. TmI: 0.25 . Leg measurements as follows: I: $0.77+0.27+0.73+0.58+0.41(2.77)$, II: $0.70+0.27+0.65+0.55+0.39$ (2.55), III: $0.61+0.23+0.49+0.52+0.33$ (2.18), IV: $0.82+0.28+0.78+0.66+0.40$ (2.94).

Palp (Figs 1A-D, 2A-C). Patella and tibia bearing 1 robust spine each, tibia with 3 trichobothria. Cymbium with a massive, triangular dorsal hump facing backward followed by a large and stumpy median tubercle. Paracymbium large, bearing several short setae on the basal area, lateral margin covered with several minute wrinkles. Two proximal radical apophyses: radical apophysis I short, robust and spine-like; radical apophysis II long, thin and thread-like, curved outward and downward. Distal radical apophysis bearing one or several robust teeth. Distal suprategular apophysis robust and curved, with a second branch more or less strongly developed depending on the population and individual. Antero-proximal part of median membrane with a row of 8-10 stumpy teeth. Terminal apophysis clearly visible, ending with a wide, wrinkled tip. Embolus curved, ending in a sharp point.

\section{Female}

Habitus. See Fig. 1I.

Measurements. Total length 1.87-2.15. Carapace 0.81 long, 0.58 wide.

Prosoma and abdomen. As in male. Abdomen usually darker, with marks more visible than in the male.

Legs. As in male. Leg measurements as follows: I: $0.62+0.30+0.60+0.43+0.41$ (2.35), II: $0.61+0.26+0.50+0.44+0.35(2.17)$, III: $0.59+0.22+0.45+0.42+0.35(2.03)$, IV: $0.74+0.26+0.67+0.54+0.37(2.58)$. 

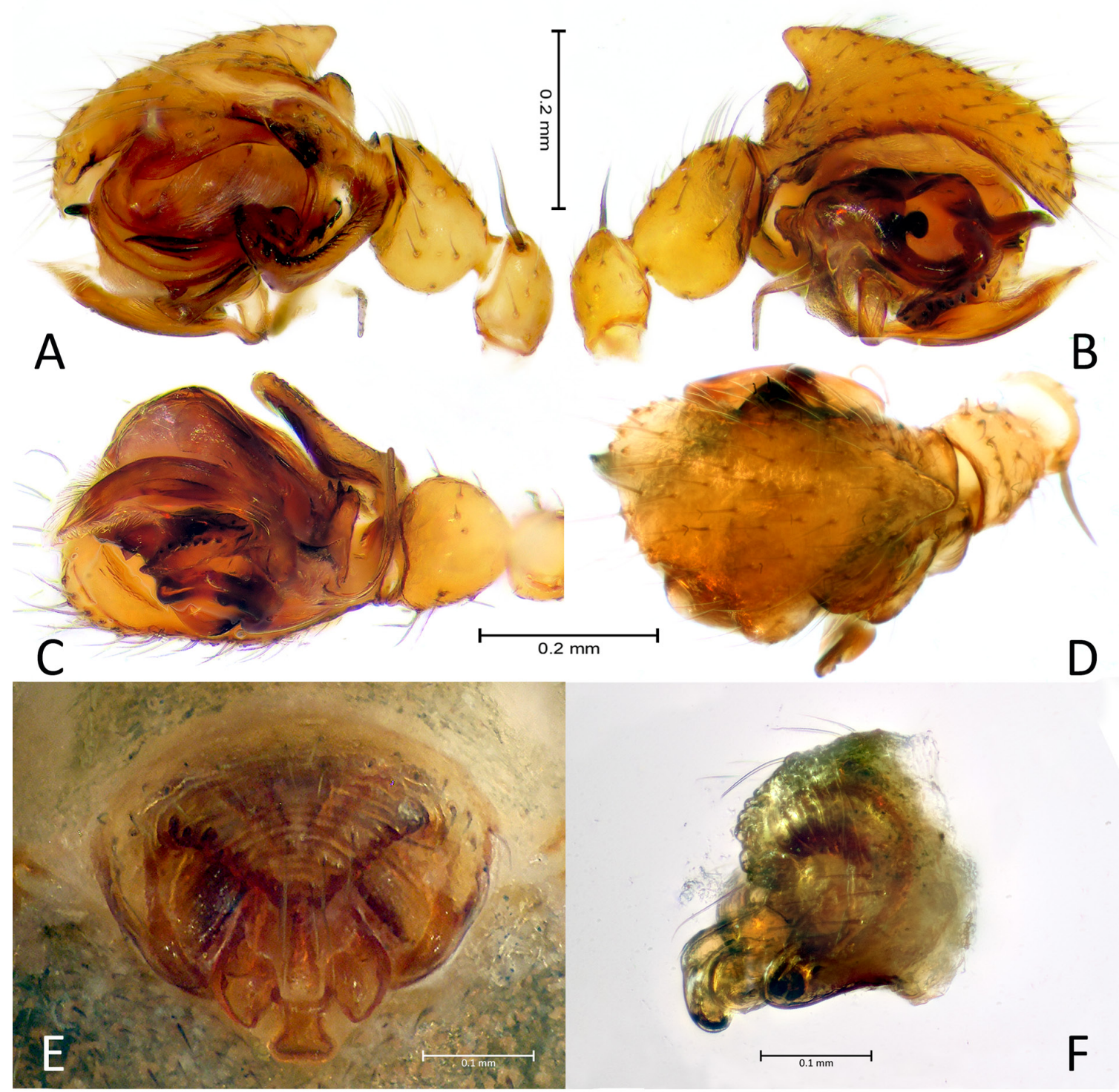

$\mathrm{F}$
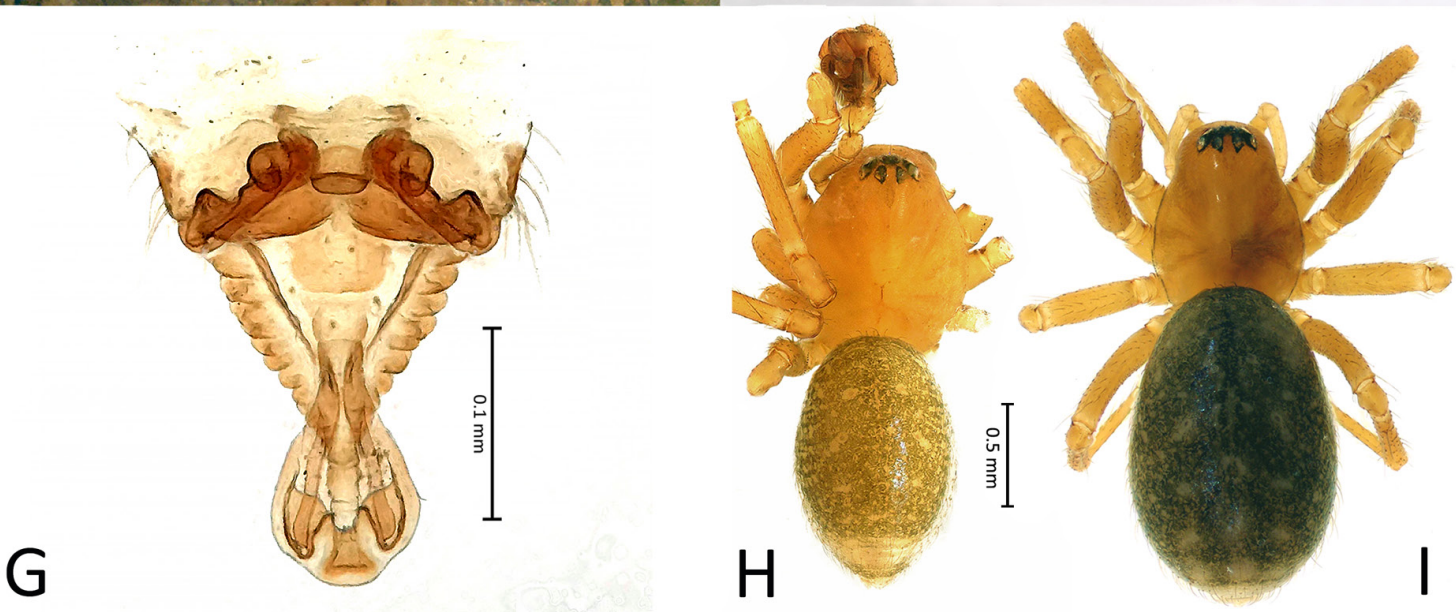

Fig. 1. Centromerus tongiorgii sp. nov., from Grezzana. A. Male palp, retrolateral view. B. Ditto, prolateral view. C. Ditto, ventral view. D. Ditto, dorsal view. E. Epigyne, ventral view, F. Ditto, lateral view. G. Vulva after maceration, dorsal view. H. Male habitus. I. Female habitus. 
Epigyne AND vUlva (Figs 1E-G, 2D-E). Anterior wall triangular, strongly wrinkled, covering a large epigynal cavity, ending with a truncated tip and lacking a clear ending lobe. Distal part of scapus wide, lobate, strongly protruding from the epigynal cavity. Posterior median plate small and rectangular, longer than wide. Spermathecae elongated and S-shaped. Copulatory grooves first turning posteriorly and outward before returning to the middle part of the vulva and ending in copulatory openings in the distal part of the scapus.

\section{Distribution}

Endemic to Italy. Distributed along the Alpine and Apennine mountain ranges, from the Lessini Mountain Prealps to the Aspromonte massif, see Fig. 10.

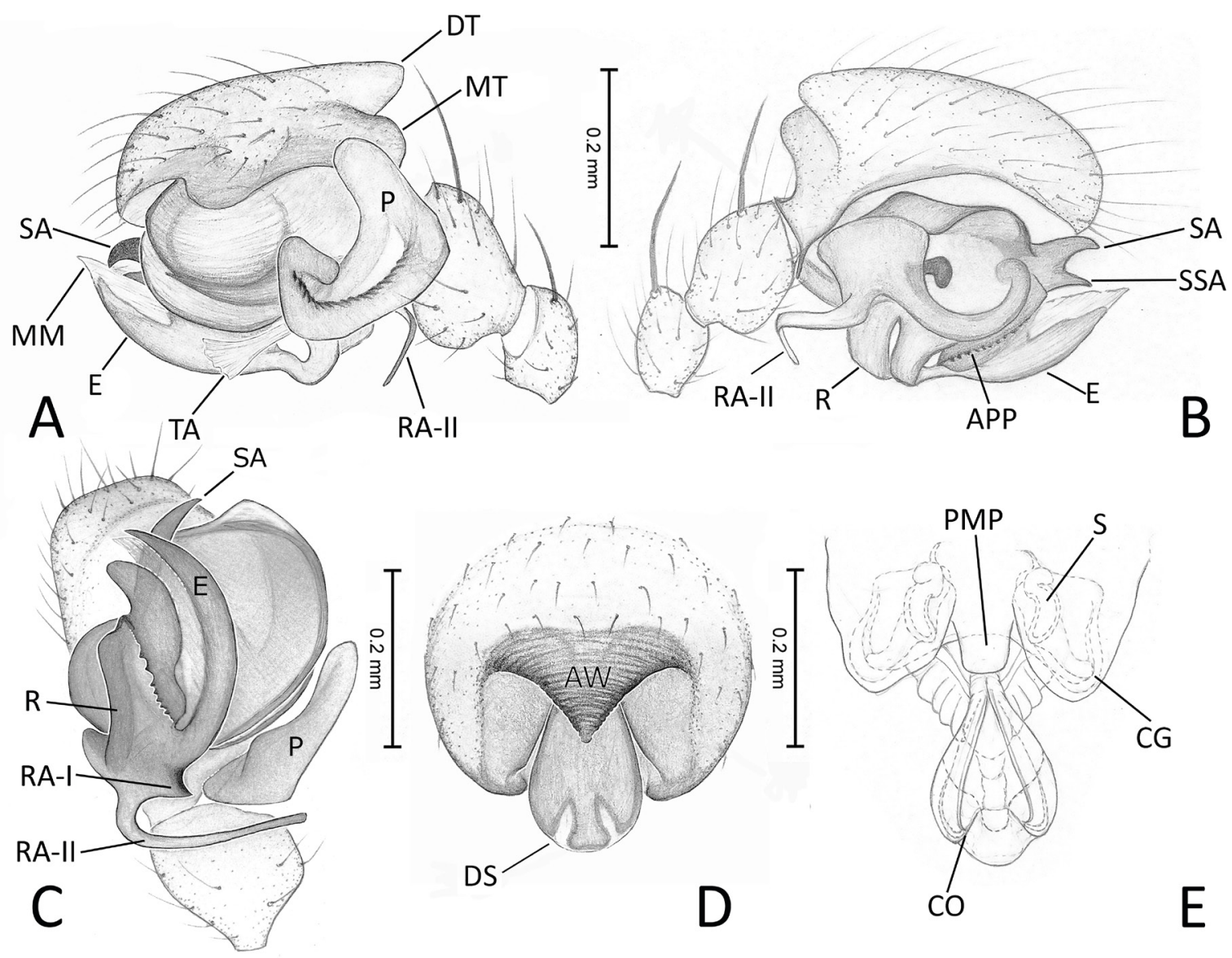

Fig. 2. Centromerus tongiorgii sp. nov., from Endine Gaiano. A. Male palp, retrolateral view. B. Ditto, prolateral view. C. Ditto, ventral view. D. Epigyne, ventral view. E. Vulva, dorsal view. 
Centromerus hanseni sp. nov. urn:1sid:zoobank.org:act:DABE9924-06A9-4ED5-9CA8-F4246BCD9902

Figs $3-4,10$

\section{Diagnosis}

Males of the new species generally resemble male Centromerus tongiorgii sp. nov., C. semiater and C. sellarius. They can easily be separated from males of the other three species by the presence of a welldeveloped radical apophysis I (RA-I) which is clearly visible when the palp is observed prolaterally or retrolaterally, in contrast to the absent or non-visible RA-I in males of the other three species. A further diagnostic character is the square, stocky dorsal hump (DT) of male $C$. hanseni sp. nov., which appears triangular and ending with a sharp or rounded tip in the other three species. In addition, male $C$. hanseni sp. nov. can easily be separated from male $C$. tongiorgii sp. nov. and $C$. semiater by the presence of a well-developed apophysis in the distal part of the paracymbium (APC), clearly visible when the palp is observed ventrally (Fig. 4C), absent in the other two species.

The epigyne of female $C$. hanseni sp. nov. is similar to that of female $C$. tongiorgii sp. nov., $C$. isaiai and C. sylvaticus. However, female $C$. hanseni sp. nov. can be distinguished by the narrower and truncated anterior wall (AW); the other species have a wider AW, always ending with a sharp or lobate tip. The different shape of the posterior median plate (PMP) further distinguishes these species, as the PMP is squared in $C$. hanseni sp. nov., but, in contrast, rectangular in $C$. tongiorgii sp. nov., triangular in C. isaiai and trapezoid in C. sylvaticus (see Figs 3G, 4E vs Figs 1G, 2E vs Bosmans \& Colombo 2015: fig. 13 and Wiehle 1956: fig. 55). In addition, the small size of both males and females easily separates the new species from the large majority of other species of Centromerus, which generally show a larger body size.

\section{Etymology}

The specific name is a patronym in honor of Harald Hansen, an Italian arachnologist from Venice who recently passed away (Uliana 2018). Hansen widely contributed to the study of the Italian spider fauna, in particular the family Salticidae.

\section{Material examined}

\section{Holotype}

ITALY • đ’; Calabria Region, Cosenza, Fagnano Castello, Trifoglietti Lake; $39.5489^{\circ} \mathrm{N}, 16.0229^{\circ} \mathrm{E}$; 1050 m a.s.1.; Aug. 2016-May 2017; beechwood, in the litter; pitfall traps; M. Valle leg.; MSNB.

\section{Paratypes}

ITALY - Calabria Region • 1 q; same locality as for holotype; Aug. 2013-Aug. 2014; M. Valle leg.;

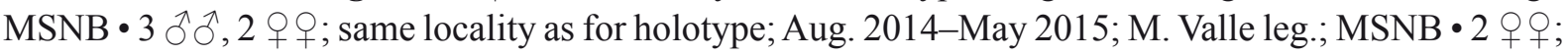
same locality as for holotype; Aug. 2015-Aug. 2016; M. Valle leg.; MSNB • 1 o, 1 क; same locality as for holotype; Aug. 2016-May 2017; M. Valle leg.; MSNB • 1 đ; Reggio Calabria, Bagaladi, Nucarelle; $38.0553^{\circ} \mathrm{N}, 15.812^{\circ} \mathrm{E}$; $1100 \mathrm{~m}$ a.s.1.; Nov. 2013-Jun. 2014; beechwood; pitfall traps; E. Castiglioni and F. Manti leg.; MSNB • 4 đôं; Reggio Calabria, San Luca, Serra Juncari; $38.1559^{\circ}$ N, $15.9367^{\circ}$ E; 1750 m a.s.l.; Nov. 2013-Apr. 2014; mixed wood with beech (Fagus sylvatica), juniper (Juniperus communis) and pine trees (Pinus sp.); pitfall traps; E. Castiglioni and F. Manti leg.; MSNB.

\section{Description}

Male

Habitus. See Fig. 3H. 

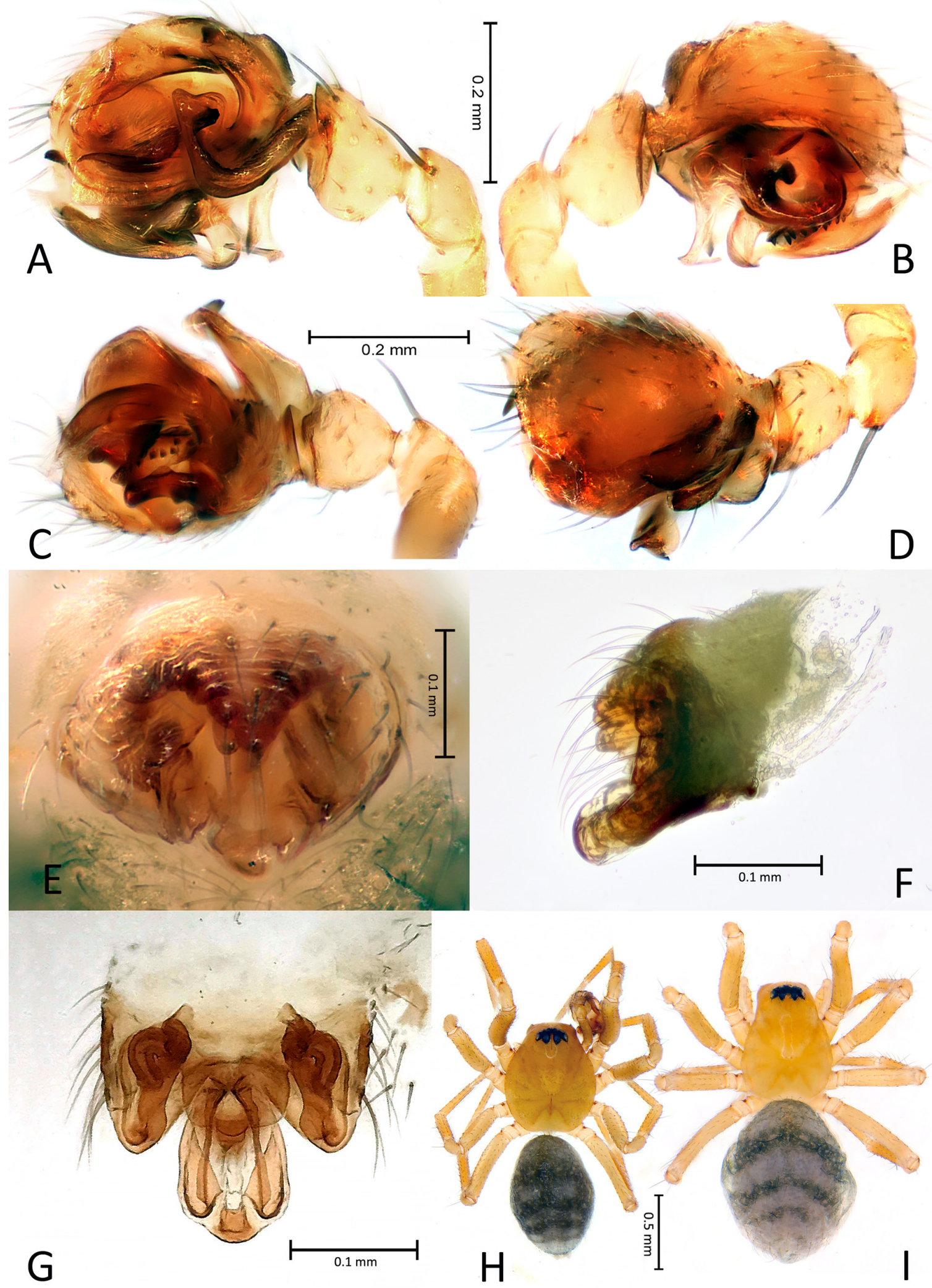

Fig. 3. Centromerus hanseni sp. nov., from Trifoglietti Lake. A. Male palp, retrolateral view. B. Ditto, prolateral view. C. Ditto, ventral view. D. Ditto, dorsal view. E. Epigyne, ventral view. F. Ditto, lateral view. G. Vulva after maceration, dorsal view. H. Male habitus. I. Female habitus. 
Measurements. Total length $1.55-2.05$. Carapace 0.71 long, 0.52 wide.

Prosoma. Carapace uniformly yellowish, chelicerae, labium and gnathocoxae of the same color. Chelicera with stridulatory ridges on the lateral margin. Three teeth at the anterior margin of the fang groove, posterior margin with 4-5 small denticles. Sternum greyish.

AвDOMEN. Greyish with 3-4 V-shaped lighter stripes, sometimes reduced to simple marks barely visible in some specimens.

Legs. Uniformly yellowish. Femur I with 1 prolateral spine. Tibial spine formula: 2221. TmI: 0.25 . Leg measurements as follows: I: $0.73+0.23+0.68+0.52+0.38(2.54)$, II: $0.67+0.23+0.58+0.47+0.38$ (2.33), III: $0.55+0.21+0.47+0.43+0.35$ (2.01), IV: $0.75+0.21+0.66+0.56+0.37(2.56)$.

PaLp (Figs 3A-D, 4A-C). Patella and tibia bearing one robust spine each, tibia with 3 trichobothria. Cymbium with a stocky, squared dorsal hump. Paracymbium large, with a robust, pointed apophysis headed outward on the distal part, lateral margin covered with several minute wrinkles. Two proximal radical apophyses, one robust, spine-like, the other long, thin and thread-like, both curved outward and

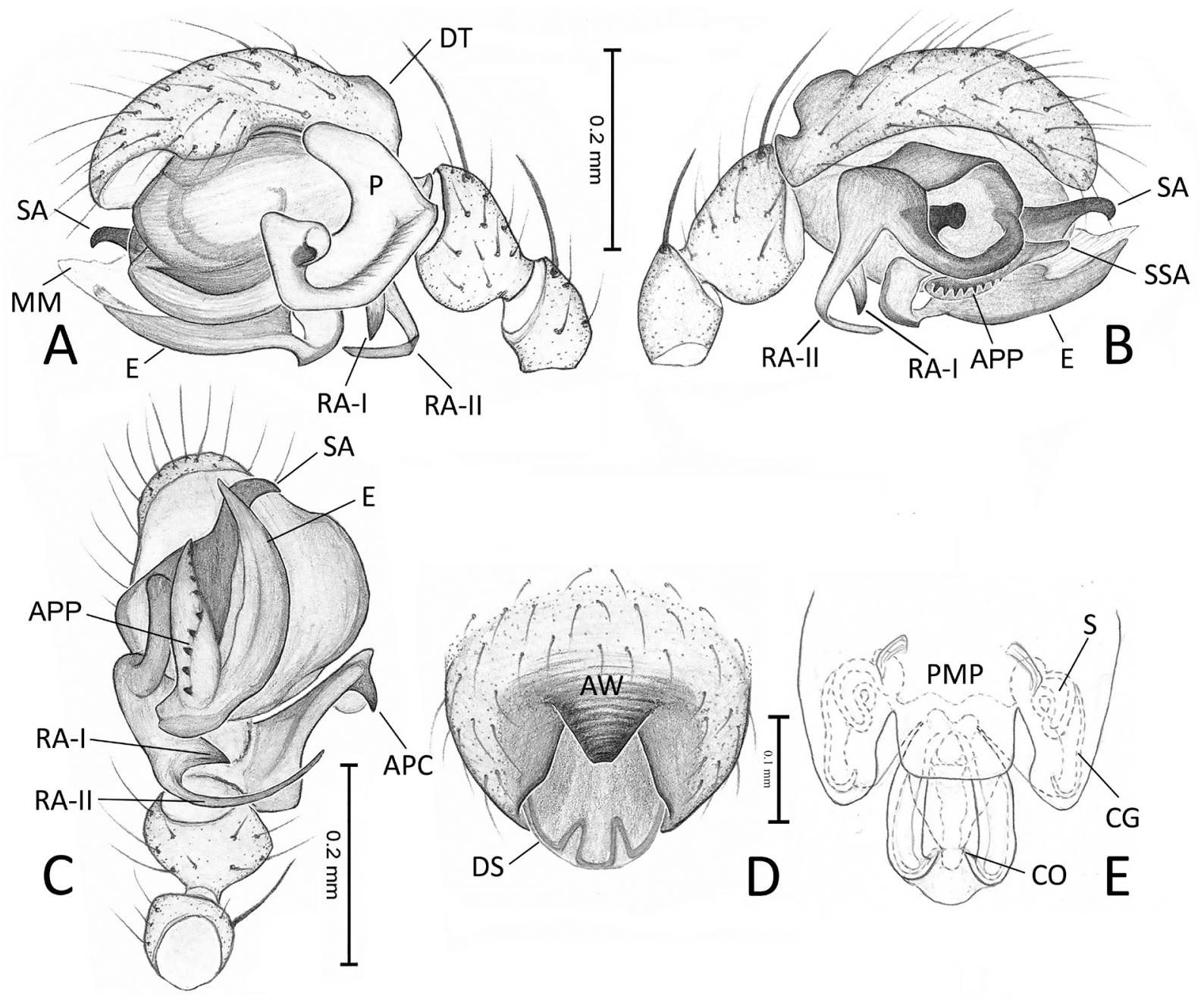

Fig. 4. Centromerus hanseni sp. nov., from Trifoglietti Lake. A. Male palp, retrolateral view. B. Ditto, prolateral view. C. Ditto, ventral view. D. Epigyne, ventral view. E. Vulva, dorsal view. 
downward. Distal radical apophysis with several minute denticles. Distal suprategular apophysis robust and curved outward, second branch shorter. Antero-proximal part of median membrane with a row of 9-10 small, stumpy teeth. Terminal apophysis transparent and scarcely visible, ending with a wide, flat and wrinkled tip. Embolus curved, ending in a sharp point.

\section{Female}

Habitus. See Fig. 3I.

MeAsuRements. Total length 1.7-1.9. Carapace 0.82 long, 0.67 wide.

Prosoma AND ABDOMEn. As in male. Abdomen with more marked and wider light stripes.

Legs. As in male. Leg measurements as follows: I: $0.56+0.22+0.46+0.35+0.34$ (1.92), II: $0.51+0.18+0.40+0.34+0.30(1.72)$, III: $0.42+0.18+0.31+0.31+0.27(1.49)$, IV: $0.59+0.17+0.51+0.39+0.31(1.96)$.

EPIGYNE AND vUlVA (Figs 3E-G, 4D-E). Anterior wall triangular and strongly wrinkled, covering a large epigynal cavity, ending with a truncated, squared tip. Distal part of scapus wide, strongly protruding from the epigynal cavity. Posterior median plate large and rectangular, wider than longer. Spermathecae small, comma-like. Copulatory grooves first turning posteriorly and outward before returning to the middle part of the vulva and ending in copulatory openings at the distal part of the scapus.

\section{Distribution}

Endemic to Italy. Distributed along the Calabrian Apennine mountain range, see Fig. 10.

Centromerus gatoi sp. nov.

urn:1sid:zoobank.org:act:E18DBDAC-6CCE-4598-B092-13D921CCAC0B

Figs 5-6, 10

\section{Diagnosis}

Species closely related to Centromerus milleri Deltshev, 1974. Males of the new species can be distinguished from male $C$. milleri by the different shape of the dorsal hump of the cymbium (DT), shorter and larger in C. gatoi sp. nov. in contrast to the longer and thinner hump in C. milleri, and by the presence of a massive, stocky apophysis in the proximal part of the paracymbium (APC), lacking in C. milleri (see Figs 5A, 6A vs Deltshev 1974: figs 4-5 and Dimitrov \& Deltshev 2019: figs 5-6, 15-16). Females of the new species are distinguished from female $C$. milleri by the more protruding epigyne (shorter in C. milleri), with a proportionally longer basal part of the scapus and lateral lobes of the anterior wall (LAW) (see Figs 5E-G, 6D-F vs Deltshev 1974: figs 7-9 and Dimitrov \& Deltshev 2019: figs $10-12,20-22)$.

\section{Etymology}

The specific name is a patronym in memory of our friend Federico 'Gato' Mazzoleni, a young and promising Italian arachnologist who prematurely passed away. Federico first recognized this new species.

\section{Material examined}

\section{Holotype}

ITALY - O'; Calabria Region, Reggio Calabria, Santo Stefano d'Aspromonte, Ponte Sant'Antonio, Valone di Pilima; $38.1876^{\circ} \mathrm{N}, 15.8466^{\circ}$ E; 1260 m a.s.1.; Nov. 2013-Oct. 2014; beechwood, in the litter; pitfall traps; E. Castiglione and F. Manti leg.; MSNB. 


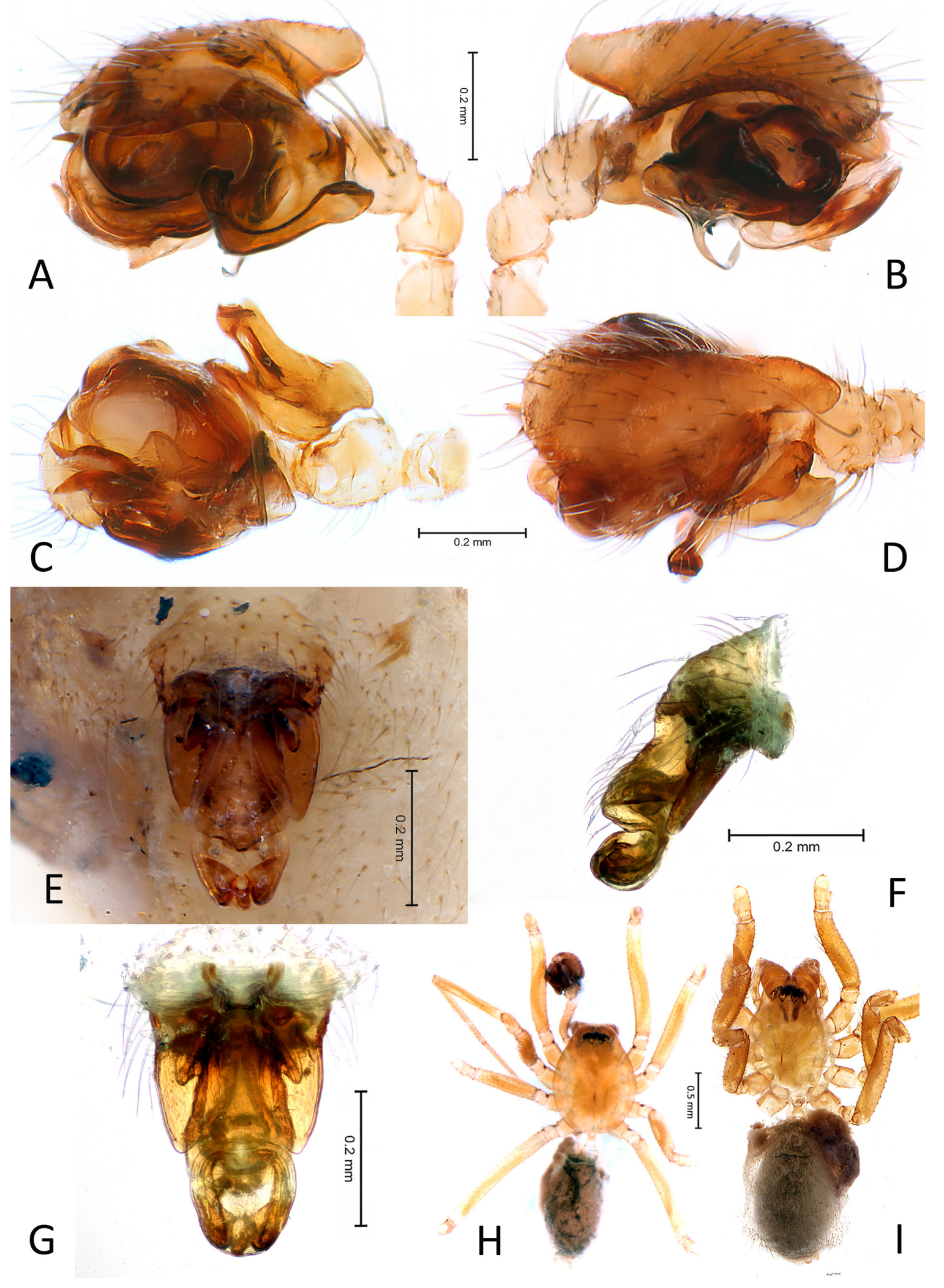

Fig. 5. Centromerus gatoi sp. nov., from Ponte Sant'Antonio. A. Male palp, retrolateral view. B. Ditto, prolateral view. C. Ditto, ventral view. D. Ditto, dorsal view. E. Epigyne, ventral view. F. Ditto, lateral view. G. Vulva after maceration, dorsal view. H. Male habitus. I. Female habitus. 


\section{Paratypes}

ITALY - Calabria Region • 1 क; Reggio Calabria, Santo Stefano d'Aspromonte, Gambarie; $1300 \mathrm{~m}$ a.s.1.; Jun. 1990-Jun. 1991; pitfall traps; G. Buttarelli, E. Ghilardi, P. Pantini and M. Valle leg.; MSNB • 1 +; Reggio Calabria, Santo Stefano d'Aspromonte, between Gambarie and Montalto; 1500 m a.s.1.; Jun. 1990-Jun. 1991; pitfall traps; G. Buttarelli, E. Ghilardi, P. Pantini and M. Valle leg.; MSNB • 1 \%; Reggio Calabria, Santo Stefano d'Aspromonte, Ponte Sant'Antonio, Valone di Pilima; $38.1876^{\circ} \mathrm{N}, 15.8466^{\circ} \mathrm{E}$; 1260 m a.s.1.; 13 Nov. 2013; beechwood, in the litter; E. Castiglione, F. Manti and P. Pantini leg.; MSNB - 1 Ō, 2 우; same locality as for preceding; Nov. 2013-Oct. 2014; pitfall traps; E. Castiglione and F. Manti leg.; MSNB.

\section{Comparative material}

BULGARIA 11 , holotype of C. milleri Deltshev, 1974, 1 , , paratype; Eastern Rhodopes, Kartjali town, Karangil Cave, 2 Apr. 1972; Kolev B. leg.; NMNS.

\section{Description}

The available specimens were in a poor condition of preservation; thus, the colouration of the species might be slightly different in life.

\section{Male}

Habitus. See Fig. 5H.

MeAsurements. Total length 2.73-3.01. Carapace 1.14 long, 0.95 wide.

Prosoma. Carapace uniformly yellowish-brown, chelicerae, labium and gnathocoxae of the same colour. Chelicera with stridulatory ridges on the lateral margin. Three teeth at the anterior margin of the fang groove, posterior margin with 4-5 small denticles. Sternum greyish.

ABDOMEN. Covered with sparse setae, uniformly greyish with lighter marks barely visible on the dorsal side, distal end with a lighter area.

LEGS. Uniformly yellowish-brown. Femur I with 1 prolateral spine. Tibial spine formula:. 2-2-?-? (tibiae III and IV missing). TmI:. 0.46. Leg measurements as follows: I: $1.37+0.37+1.42+1.31+0.84(5.31)$, II: $1.21+0.36+1.25+1.19+0.78$ (4.80), III: $1.17+0.36+$ missing, IV: $1.47+0.30+$ missing.

PaLP (Figs 5A-D, 6A-C). Patella with a single thin spine, tibia bearing 3 trichobothria and 3 robust spines. Cymbium with a massive, elongated dorsal hump facing backward. Paracymbium large, with a stocky apophysis facing backward in the proximal part of the lateral margin. Lateral margin of the paracymbium lacking wrinkles or denticles. Radical apophysis long, thin, thread-like, curved downward and outward. Distal radical apophysis, bearing 2 robust teeth. Distal suprategular apophysis with two robust and curved branches, the second branch shorter than the first branch in some specimens, and the same length as the first branch in others. Antero-proximal part of median membrane lacking any teeth. Terminal apophysis ending with a wide, curved and serrated lobe. Embolus curved, narrow at the base and thickening distally, with sharp tip.

\section{Female}

Habitus. See Fig. 5I.

Measurements. Total length 2.72-3.33. Carapace 1.25 long, 0.76 wide.

Prosoma And ABDomen. As in male. 
Legs. As in male. Leg measurements as follows: I: $1.28+0.39+1.26+1.16+0.74$ (4.84), II: $1.22+0.36+1.16+1.08+0.67 \quad$ (4.49), III: $1.10+0.34+0.98+1.03+0.62 \quad$ (4.08), IV: $1.48+0.39+$ missing.

Epigyne And vulva (Figs 5E-G, 6D-G). Anterior wall wide, with a round border and two elongated lateral lobes. Basal part of scapus long and strongly protruding ventrally. Distal part of scapus wide and curved. Posterior median plate wide, rectangular, longer than wide. Spermathecae elongated and S-shaped. Copulatory grooves first turning posteriorly and outward before returning to the middle part of the vulva and ending in copulatory openings at the distal part of the scapus.

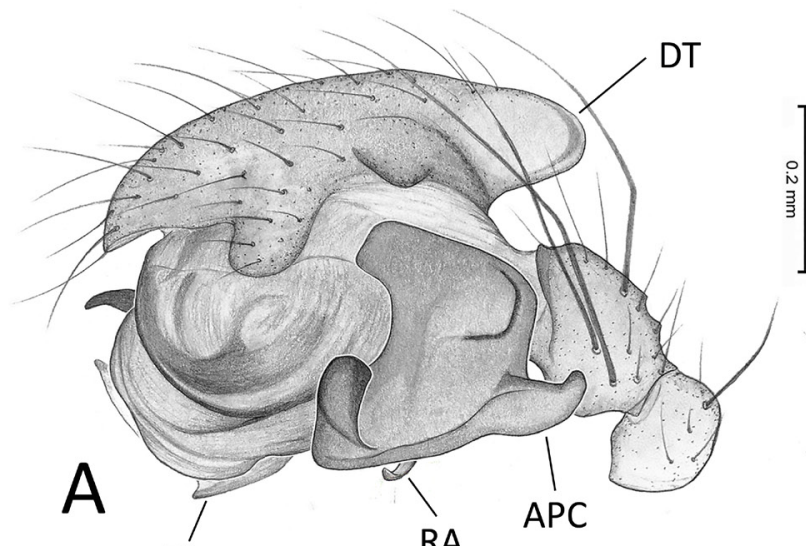

TA

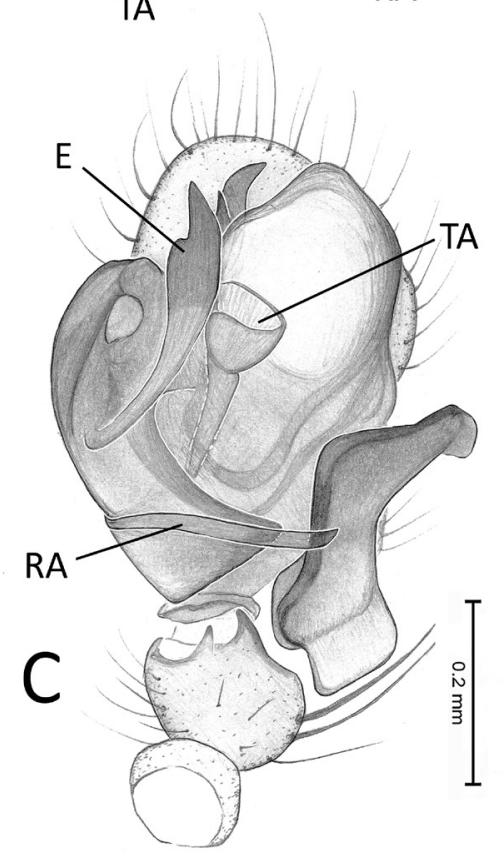

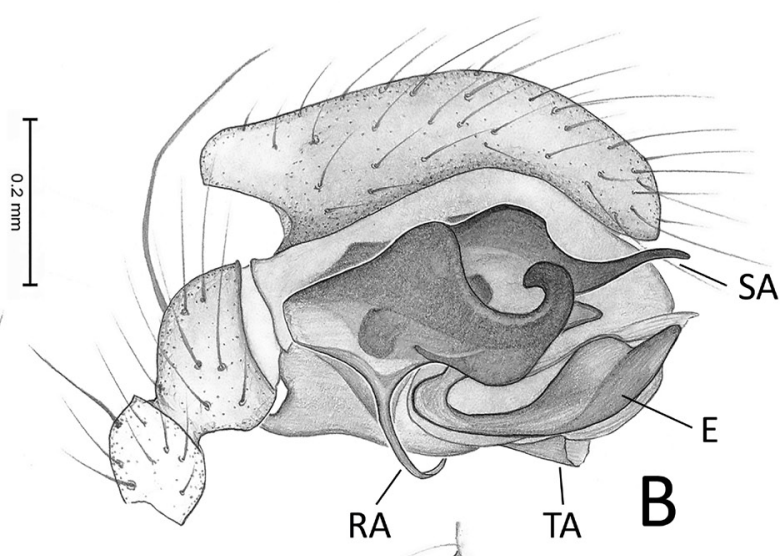

AW
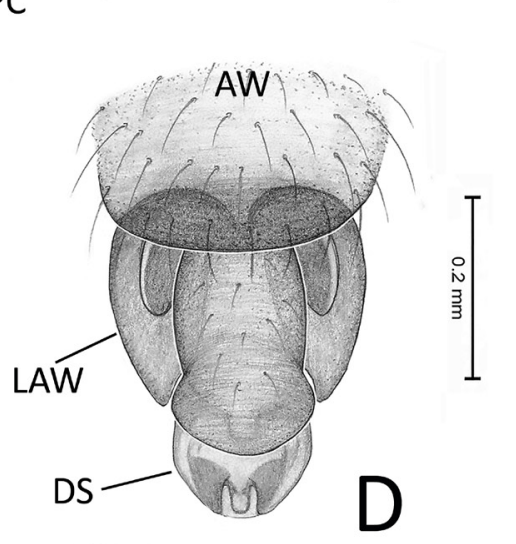

RA

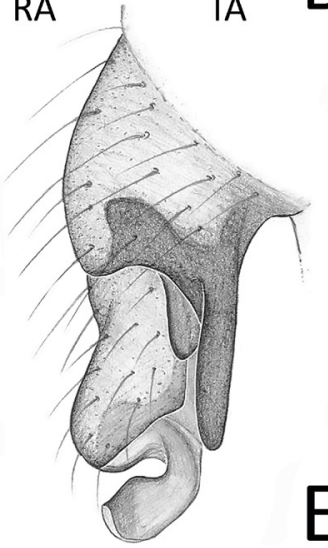

$\mathrm{E}$

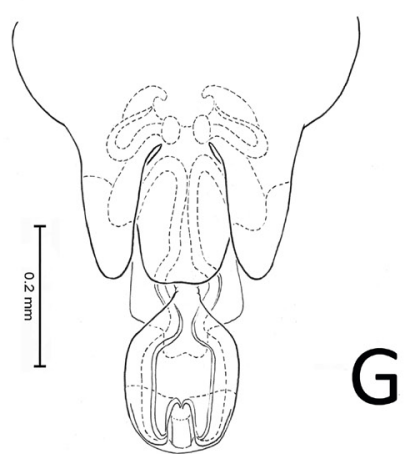

Fig. 6. Centromerus gatoi sp. nov., from Ponte Sant'Antonio. A. Male palp, retrolateral view. B. Ditto, prolateral view. C. Ditto, ventral view. D. Epigyne, ventral view. E. Ditto, lateral view. F. Ditto, ventral view. G. Vulva dorsal view. 


\section{Distribution}

Endemic to Italy. Known only from the Aspromonte massif, see Fig. 10.

\section{Centromerus cf. paradoxus (Simon, 1884)}

Figs $7 \mathrm{~A}-\mathrm{B}, 8,10$

For a complete list of references, see WSC (2020).

\section{Material examined}

ITALY - Liguria Region • 1 क; La Spezia, Portovenere, Isola Palmaria; 170 m a.s.1.; 24-28 Apr. 2003; S. Ciocca leg.; MSNB. - Umbria Region • 2 đ̂̃; Perugia, Nocera Umbra, Colle Aprico, Pendici Monte Pennino; 700 m a.s.l.; Jan.-Jun. 1992; pitfall traps; P. Pantini and M. Valle leg.; MSNB • 5 §ð, 2 q $ᄋ$; Perugia, San Giustino, near Lama village; $400 \mathrm{~m}$ a.s.l.; Jan.-Jun. 1992; pitfall traps; P. Pantini and M. Valle leg.; MSNB • 1 ð, 1 क; Perugia, Sigillo, near the village; 500-550 m a.s.1.; Jan.-Jun. 1991; pitfall traps; P. Pantini and M. Valle leg.; MSNB • $1 \hat{\jmath}, 1$ \% ; same locality as for preceding; Jun.-Dec. 1991; P. Pantini and M. Valle leg.; MSNB. - Lazio Region • 1 § ; Roma, Canale Monterano, Regional

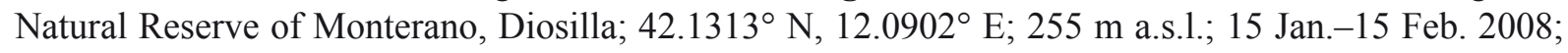
deciduous forest with black alder (Alnus glutinosa) and hornbeam (Carpinus betulus); pitfall traps; V. Rizzo and A. Vigna leg.; MSNV • 1 ô; ; same locality as for preceding; 15 Feb.-14 Mar. 2008; V. Rizzo
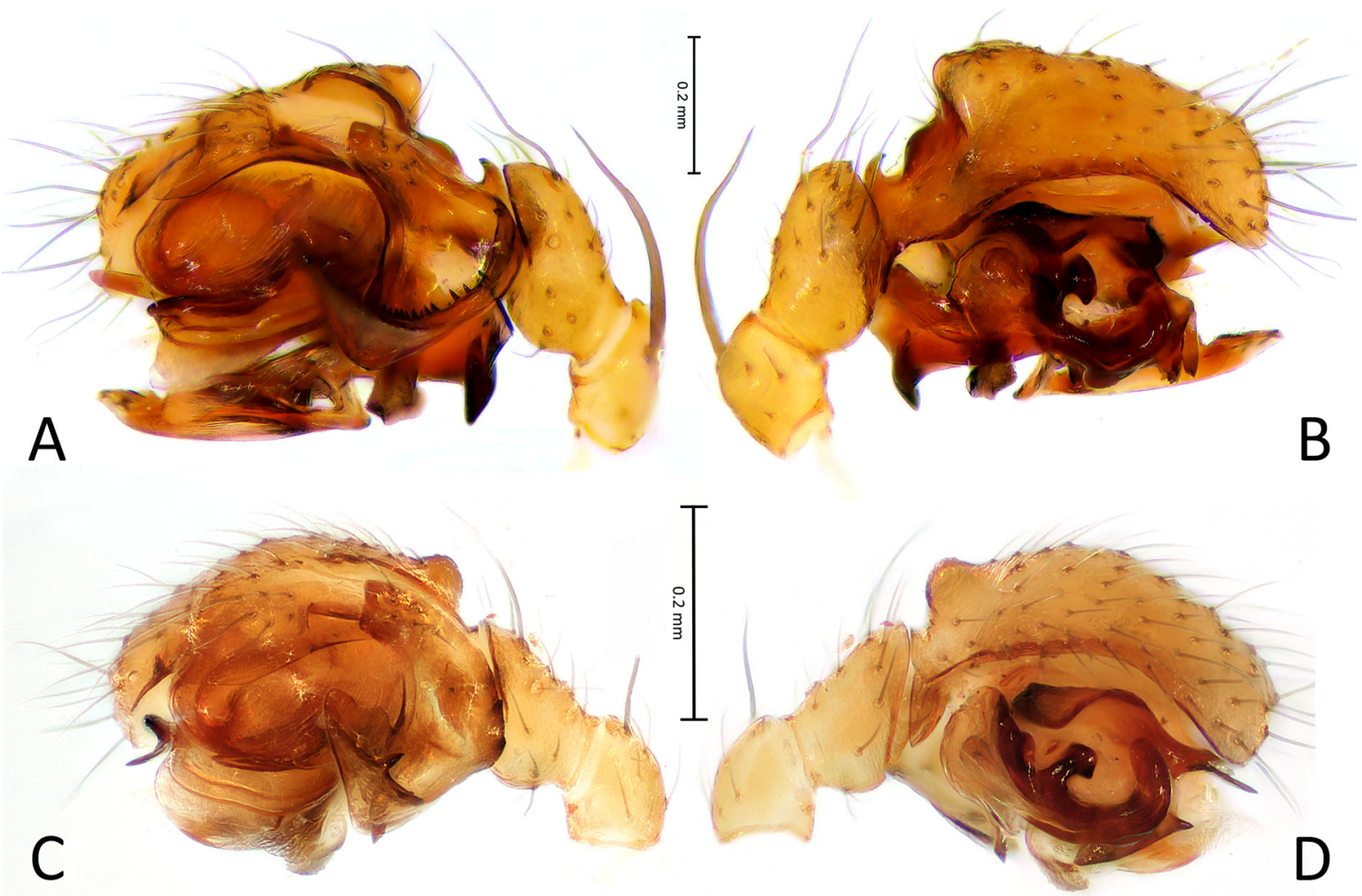

Fig. 7. A-B. Centromerus cf. paradoxus (Simon, 1884), from Canale Monterano. A. Male palp, retrolateral view. B. Ditto, prolateral view. C-D. Centromerus desmeti Bosmans, 1986, from Serra Juncari. C. Male palp, retrolateral view. D. Ditto, prolateral view. 


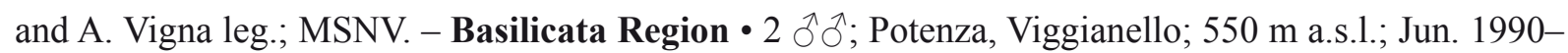
Jun. 1991; pitfall traps; G. Buttarelli, E. Ghilardi, P. Pantini and M. Valle leg.; MSNB.

Other material (Centromerus paradoxus (Simon, 1884))

SPAIN - Tarragona Province • 1 $\widehat{\partial}, 1$ क ; Ulldecona, Avenc de les Canals; 28 May 2014; EGA-MZB

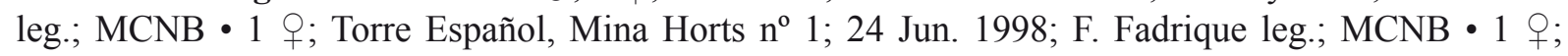
Vallclara (Conca de Barberà), Cv. del Mas de la Llana; 11 Mar. 2012; R.S. and J.P. leg.; MCNB. Castellón Province • 3 $q$; Xert, Av. Comanegra; 9 Apr. 1993; O. Escolà leg.; MCNB • 1 $\odot$; Tirig (Alt Maestrat), Cv. de Mas Abad; 15 Dec. 1996; F. Fadrique leg.; MCNB.

\section{Comparative material}

SERBIA $-\widehat{O}$, holotype of $C$. acutidentatus Deltshev, 2002, 1 + , paratype; vili. Selacka near Minicevo, Monastery Cave I, at the entrance; 15 Nov. 1997; in leaf litter; RND, OSK, VTT, SBĆ and NBĆ leg.; MHNG.

\section{Distribution}

Western Mediterranean. In Italy widespread along the entire Apennine mountain chain. See Fig. 10.

\section{Remarks}

Records of $C$. paradoxus have long been considered doubtful for the Italian fauna since Brignoli (1972), thus being omitted in the recent Catalog of the Italian Spiders by Pantini \& Isaia (2019). New

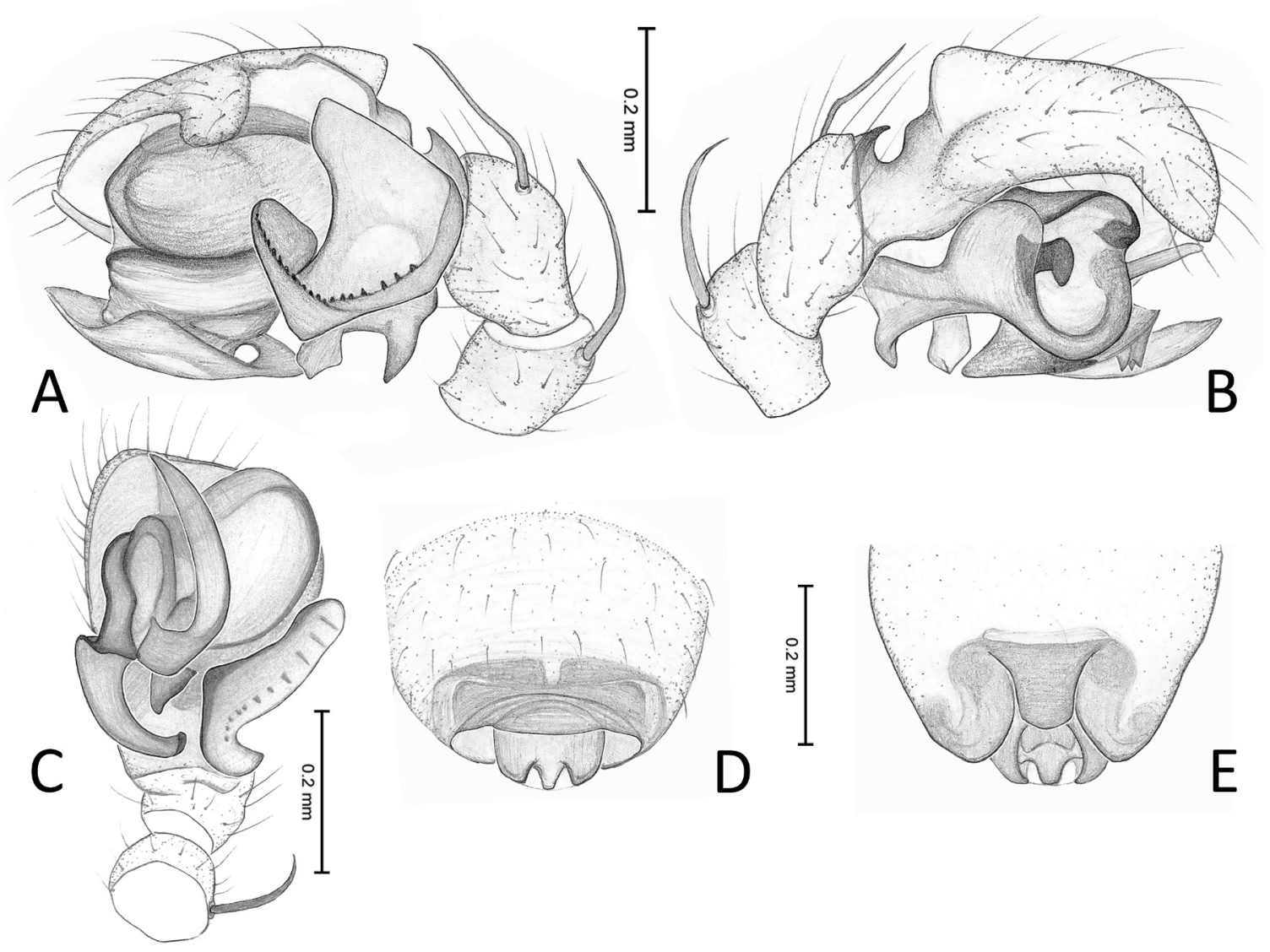

Fig. 8. Centromerus cf. paradoxus (Simon, 1884), from Sigillo. A. Male palp, retrolateral view. B. Ditto, prolateral view. C. Ditto, ventral view. D. Epigyne, ventral view. E. Vulva, dorsal view. 
records from Italy herein reported confirm the presence of a member of the paradoxus species group in the Italian peninsula. The paradoxus species group currently covers a wide distributional area across Europe, with species recorded in the Western Mediterranean (C. paradoxus (Simon, 1884)), Balearic Islands (C. ponsi Lissner, 2016), Carpathian Mountains (C. gentilis Dumitrescu \& Georgescu, 1980) and the Balkans (C. acutidentatus Deltshev, 2002 and C. obenbergeri Kratochvil \& Miller, 1938) (Nentwig et al. 2020). However, among such species, only minor differences in the diagnostic characters of palp and epigyne can be observed, making their morphological separation tricky. Such interspecific similarities suggest the presence of cryptic species or potential misidentification of one or a few species with a wide distribution and high local intraspecific variability. In light of these facts, a general revision of this species group, possibly including both morphological and molecular analysis, seems necessary to confirm the validity of the current taxonomy.

Our specimens from Italy show few morphological differences with congeners such as C. paradoxus and $C$. acutidentatus, making a specific diagnosis difficult. In our opinion, the differences observed are insufficient to establish a new species. In order to avoid further problems in the already confusing taxonomy of this group, we temporarily attribute the Italian specimens to $C$. cf. paradoxus, the species which, geographically, is most likely to be present in Italy. Further studies, involving a precise morphological and molecular comparison of all the species of this group, will allow a better identification of the Italian samples.

Centromerus serratus (O. Pickard-Cambridge, 1875)

For a complete list of references, see WSC (2020)

\section{Material examined}

ITALY - Liguria Region • 1 ô, 1 क; Genova, Mezzanego, near Giaiette; 850 m a.s.1.; 31 Oct. 2009-25 May 2010; beechwood; pitfall traps; O. Lodovici, P. Pantini and M. Valle leg.; MSNB • 1 § ; La Spezia, Varese Ligure, Passo Cento Croci; 1000 m a.s.1.; Sep. 1991-May 1992; pitfall traps; G. Buttarelli, R. Cerbino, P. Pantini and M. Valle leg.; MSNB. - Veneto Region • 3 ôj; Verona, Mezzane di Sotto, Castagnè; $45.497778^{\circ} \mathrm{N}, 11.105833^{\circ} \mathrm{E} ; 470 \mathrm{~m}$ a.s.1.; $27 \mathrm{Feb} .-4$ Mar. 2010; thermophilic undergrowth; pitfall trap; F. Ballarin leg.; MSNV - 1 क; Brenzone, Mt Baldo, $\mathrm{N}$ of Prada village, Val di Fies;

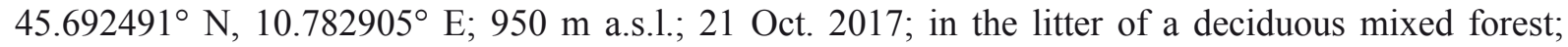
F. Ballarin leg.; MSNV. - Emilia-Romagna Region - 1 j, 1 of; Piacenza Bobbio, Passo Pernice;

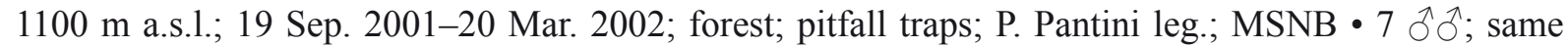

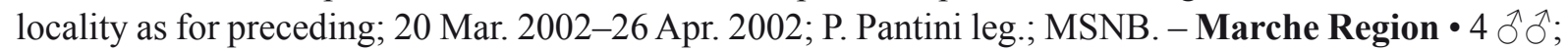
Macerata, Castelsantangelo sul Nera, Gualdo; 900 m a.s.1.; Jan. 1992-Jun. 1992; pitfall traps; P. Pantini and M. Valle leg.; MSNB - 2 ơ; Macerata, Fiuminata, near Passo Cornello; 600 m a.s.1.; Jan. 1992Jun. 1992; pitfall traps; P. Pantini and M. Valle leg.; MSNB. - Toscana Region • 7 đo , 6 q $q$; Firenze,

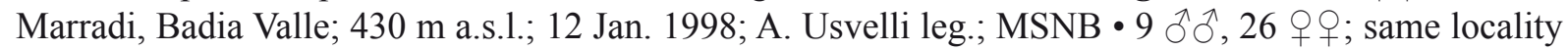
as for preceding; 6 Mar. 2003; A. Usvelli leg.; MSNB • 2 đō, 8 우; same locality as for preceding;

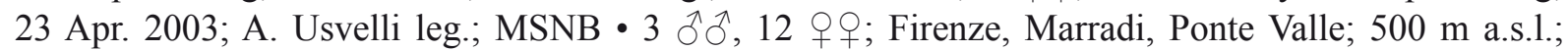
6 Mar. 2003; A. Usvelli leg.; MSNB • 1 \%; same locality as for preceding; 28 Apr. 2003; A. Usvelli leg.; MSNB • 1 क; Firenze, Marradi, Ponte Valle, Valgamogna; 800 m a.s.1.; 26 Apr. 2004; A. Usvelli leg.; MSNB. - Umbria Region • 1 ठ̊; Perugia, Nocera Umbra, Colle Aprico, Mt Pennino slopes; $700 \mathrm{~m}$ a.s.1.; Jan. 1992-Jun. 1992; pitfall traps; P. Pantini and M. Valle leg.; MSNB • 1 q; Perugia, Sigillo, Piani di Monte; 1200 m a.s.1.; Jun. 1991-Dec. 1991; pitfall traps; G. Buttarelli, E. Ghilardi, P. Pantini and M. Valle leg.; MSNB. - Abruzzo Region • 1 क; Teramo, Torricella Sicura, Monti della Laga, 1 km from Santo Stefano village heading to Rocca Santa Maria; 2 Nov. 2002; G. Osella leg.; MSNB. - Basilicata Region - 1 J; Potenza, San Severino Lucano, near the sanctuary; 1500 m a.s.1.; Jun. 1990-Jun. 1991; pitfall traps; G. Buttarelli, E. Ghilardi, P. Pantini and M. Valle leg.; MSNB. 


\section{Distribution}

Europe (Nenwig et al. 2020), widespread along the entire Italian peninsula and in Sicily (Pantini \& Isaia 2019).

\section{Remarks}

Species widely distributed, but Italian records are sparse and restricted to the north and the south of the country. Our new records confirm the presence of C. serratus in numerous regions of Central Italy.

\section{Centromerus desmeti Bosmans, 1986}

Figs $7 \mathrm{C}-\mathrm{D}, 9-10$

Centromerus desmeti Bosmans, 1986: 90, figs 8-16.

\section{Material examined}

ITALY - Calabria Region - 2 के $\hat{\partial}, 1$ क ; Reggio Calabria, San Luca, Serra Juncari; $38.1559^{\circ}$ N, $15.9367^{\circ}$ E; $1750 \mathrm{~m}$ a.s.l.; Nov. 2013-Apr. 2014; mixed wood with beech (Fagus sylvatica), juniper (Juniperus communis) and pine trees (Pinus sp.); pitfall traps; E. Castiglioni and F. Manti leg.; MSNB.

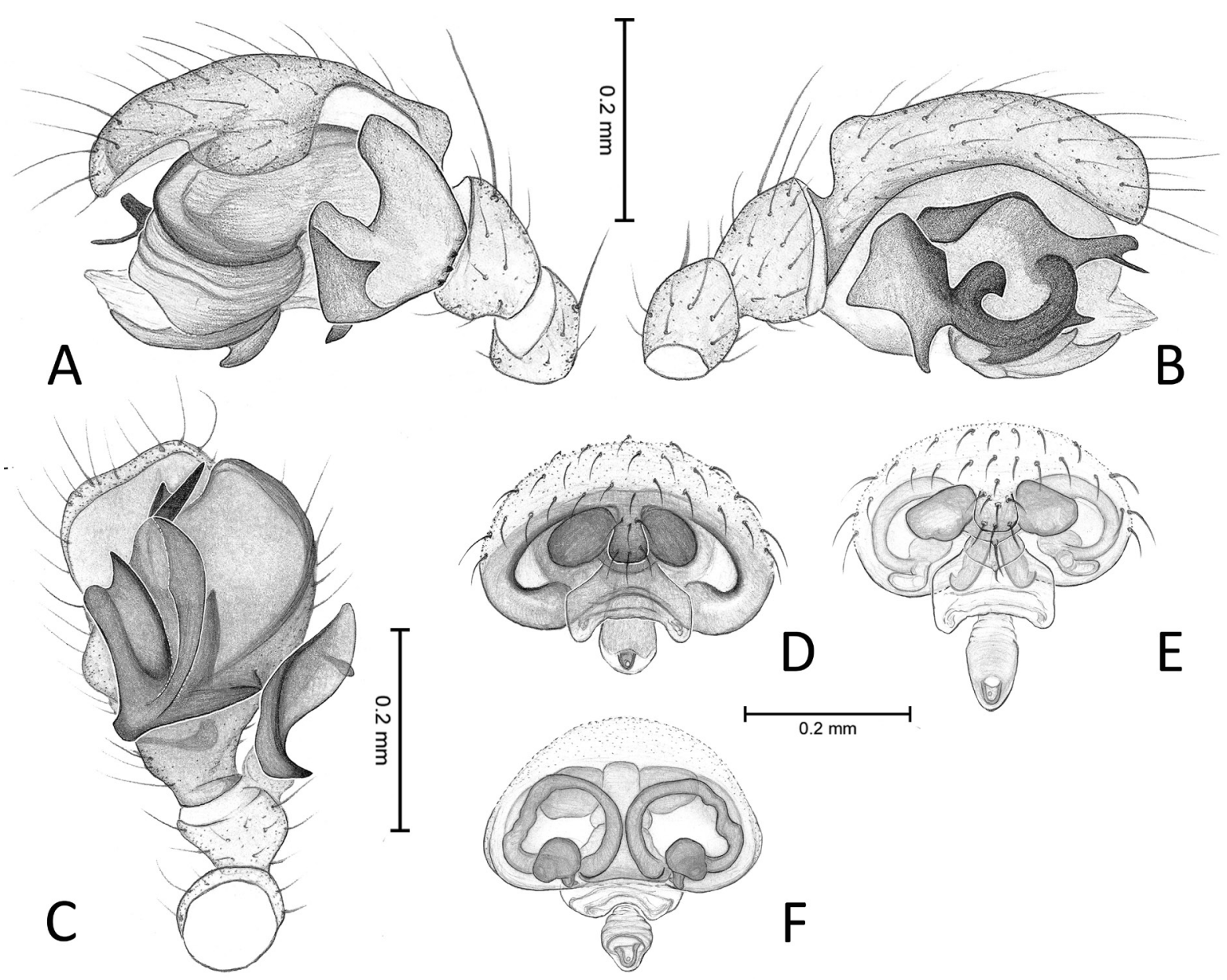

Fig. 9. Centromerus desmeti Bosmans, 1986, from Serra Juncari. A. Male palp, retrolateral view. B. Ditto, prolateral view. C. Ditto, ventral view. D. Epigyne, ventral view. E. Ditto, dorsal view. F. Vulva, dorsal view. 


\section{Distribution}

Morocco, Algeria, Majorca, Italy (Aspromonte Massif, see Fig. 10).

\section{Remarks}

This species shows a North African distribution (Bosmans 1986); previously the only European record was from the island of Majorca (Nentwig et al. 2020). New data reported here are the first record of this species for Italy and for Continental Europe.

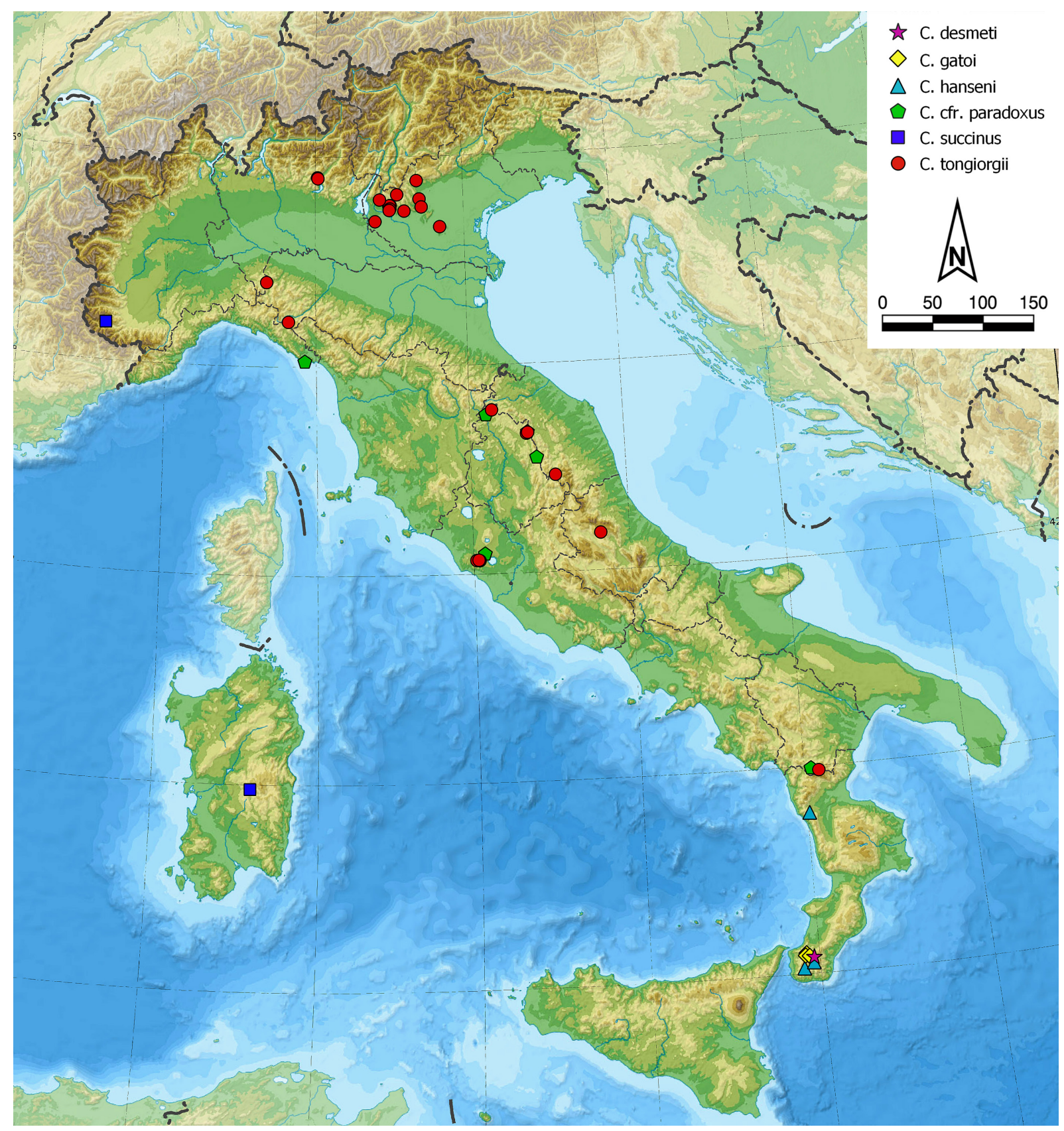

Fig. 10. Distribution in the Italian peninsula of the species $C$. tongiorgii sp. nov. (= red dots); C. hanseni sp. nov. (= azure triangles); . gatoi sp. nov. (= yellow diamonds); C. cf. paradoxus (Simon, 1884) (= green pentagons); C. desmeti Bosmans, 1986 (= violetstar); C. succinus (Simon, 1884) (= dark blue squares). 
Centromerus isaiai Bosmans, 2015

Centromerus isaiai Bosmans in Bosmans \& Colombo, 2015: 319, figs 1-14.

Centromerus isaiai - Breitling 2018: 9, fig. 2n.

\section{Material examined}

ITALY - Sardegna Region • 1 đ̂; Nuoro, Desulo, Gennargentu; hut; 1500 m a.s.l.; 9-15 Jan. 2007; pitfall traps; F. Fiori leg.; MSNB • 1 §’; Nuoro, Tonara, Su Azzime; 682 m a.s.1.; 11-18 Jan. 2008; ISE leg.; MSNB.

\section{Distribution}

Southern France, Corsica, Italy (Sardinia).

Centromerus leruthi Fage, 1933

For a complete list of references, see WSC (2020).

\section{Material examined}

ITALY - Emilia-Romagna Region • 1 Ȯ; Piacenza, Bobbio, near Passo Penice; $1100 \mathrm{~m}$ a.s.1.; 26 Apr.-27 Jun. 2002; forest; pitfall traps; P. Pantini leg.; MSNB.

\section{Distribution}

Europe, northern Italy.

\section{Remarks}

Centromerus leruthi was previously known in Italy from records from the Central Alps (Lombardia and Alto Adige regions) only. The new record reported here extends the distribution of this species to the northern Apennines.

\section{Centromerus succinus (Simon, 1884)}

Sintula succinus Simon, 1884: 451, figs 234-236 (ð̊).

Tapinasta biskrensis Simon, 1894: 647, fig. $609($ đ).

Centromerus succinus - Simon 1929: 551, 555, 724, fig. 819 (ぷ+o). — Bosmans 1986: 99, figs 34-41 $(\hat{\jmath}+)^{\prime}$.

\section{Material examined}

ITALY - Piemonte Region • 1 Ô, 4 oq ; Cuneo, Sampeyre, fr. Chiotti; 13 Nov. 2006; Rania leg.; MSNB. - Sardegna Region • 1 đ̊; Nuoro, Belvì, Canale e' Figu; 576 m a.s.1.; 11-18 Nov. 2008; pitfall traps; ISE leg.; MSNB.

\section{Distribution}

Western Mediterranean, Italy (Western Alps, Sardinia).

\section{Remarks}

This species has a Western-Mediterranean distribution (Nentwig et al. 2020). Previously, C. succinus was known in Italy only for a few specimens collected in Sardinia (Bosmans \& Colombo 2015; Pantini \& 
Isaia 2019). New records reported herein extend the distribution of this species to the northern Italian Peninsula, see Fig. 10.

\section{Discussion}

Among the Italian linyphiid fauna, the genus Centromerus appears to be well diversified and speciesrich. Our study increases the number of species recorded from Italy to 30, nine of which are considered endemic to a few localities in Sardinia or the Italian peninsula. The taxonomy and biogeography of species of Centromerus in Italy has long been neglected by modern arachnologists; most of the local species were studied and described by Brignoli in the 1970s (Pantini \& Isaia 2019). Only in the last few years has this genus been revised, with the recent discovery of new species (Bosmans \& Colombo 2015; Bosmans \& Gasparo 2015). The new records reported herein and the description of a further three new species (and a potential fourth), suggest that our knowledge regarding the Italian fauna of Centromerus, and the family Linyphiidae in general, is deficient. Such a lack of information not only involves the traditionally poorly-explored Italian southern regions or main islands, but also the much better-studied northern area, as highlighted by our discovery of $C$. tongiorgii sp. nov., a widespread species. Further collection and study regarding the Italian linyphiid fauna is likely to lead to the discovery of several new species.

\section{Acknowledgments}

The authors are particularly grateful to all the people who directly contributed to this study by collecting the studied material, in particular: Elvira Castiglioni, Francesco Manti, Davide Nardi, Laura Reich, Alberto Sette, Camilla De Stefanis, Marco Valle and Augusto Vigna Taglianti. We warmly thank Leonardo Latella and Katsuyuki Eguchi for providing support and the use of laboratory facilities, respectively, at the Museo Civico di Storia Naturale of Verona, Italy and at the Tokyo Metropolitan University, Japan. Many thanks to Christo Delshev and Dragomir Dimitrov (Sofia, Bulgaria), Robert Bosmans (Ghent, Belgium), Peter J. Schwendinger (Geneva, Switzerland) and Glòria Masó Ros (Barcelona, Spain) for kindly providing comparative material and useful information. Thanks to Elena Pelizzoli for realizing the drawings used in the plates. The English text of an early version of the manuscript was kindly edited by Victoria Smith (Canterbury Museum, New Zealand). The manuscript greatly benefitted from comments and suggestions by Andrei V. Tanasevitch (Moscow, Russia) and an anonymous reviewer. This study was supported by the 'Prof. Sandro Ruffo' grant, municipality of Verona, Italy and the YF2018 Japan Society for the Promotion of Science (JSPS KAKENHI n ${ }^{\circ}$ FF 18380) Postdoctoral Fellowships, Japan.

\section{References}

Bosmans R. 1986. Études sur les Linyphiidae Nord-Africaines IV. Le genre Centromerus Dahl (Araneae: Linyphiidae.). Biologisch Jaarboek Dodonaea 54: 85-103.

Bosmans R. \& Colombo M. 2015. New species of spiders from Sardinia (Araneae), with ecological notes on Lipocrea epeiroides (O. Pickard-Cambridge, 1872) (Araneae: Araneidae). Arachnology 16 (9): 319-332. https://doi.org/10.13156/arac.2015.16.9.319

Bosmans R. \& Gasparo F. 2015. A new cave-dwelling Centromerus from Sardinia (Araneae: Linyphiidae). Fragmenta Entomologica 46 (1-2): 113-116. https://doi.org/10.4081/fe.2014.73

Breitling R. 2018. Eric Duffey's spider collection in the Manchester Museum - an update. Newsletter of the British Arachnological Society 141: 5-9.

Brignoli P.M. 1972. Catalogo dei ragni cavernicoli italiani. Quaderni di speleologia, Circolo Speleologico Romano 1: 5-211. 
Deltshev C. 1974. A new Centromerus from Bulgarian caves (Araneae, Linyphiidae). International Journal of Speleology 6: 81-86. https://doi.org/10.5038/1827-806X.6.1.2

Dimitrov D. \& Deltshev C. 2019. Contribution to the study of the genus Centromerus in Turkey, with the description of a new species of blind spiders (Arachnida, Araneae: Linyphiidae). Revue suisse de Zoologie 126 (2): 261-267. https://doi.org/10.5281/zenodo.3463463

Helsdingen P.J. van. 1965. Sexual behaviour of Lepthyphantes leprosus (Ohlert) (Araneida, Linyphiidae), with notes on the function of the genital organs. Zoologische Mededelingen 41: 15-42.

Helsdingen P.J. van, Thaler K. \& Deltshev C. 1977. The tenuis group of Lepthyphantes Menge (Araneae, Linyphiidae). Tijdschrift voor Entomologie 120: 1-54.

Hormiga G. 2000. Higher level phylogenetics of erigonine spiders (Araneae, Linyphiidae, Erigoninae). Smithsonian Contributions to Zoology 609: 1-160.

Nentwig W., Blick T., Gloor D. Hänggi A. \& Kropf C. 2020. Spiders of Europe. Version 02.2020. Available from www.araneae.nmbe.ch [accessed 14 Feb. 2020].

Pantini P. \& Isaia M. 2019. Araneae.it: the online Catalog of Italian spiders with addenda on other arachnid orders occurring in Italy (Arachnida: Araneae, Opiliones, Palpigradi, Pseudoscorpionida, Scorpiones, Solifugae). Fragmenta Entomologica 51 (2): 127-152. https://doi.org/10.4081/fe.2019.374 Available from www.araneae.it [accessed 14 Feb. 2020].

Roberts M.J. 1987. The Spiders of Great Britain and Ireland, Volume 2: Linyphiidae and Check List. Harley Books, Colchester, UK.

Saaristo M.I. \& Tanasevitch A.V. 1996. Redelimitation of the subfamily Micronetinae Hull, 1920 and the genus Lepthyphantes Menge, 1866 with descriptions of some new genera (Aranei, Linyphiidae). Berichte des Naturwissenschaftlich-Medizinischen Vereins in Innsbruck 83: 163-186.

Simon E. 1884. Les arachnides de France. Tome cinquième, deuxième et troisième partie. Roret, Paris, $180-885$.

Simon E. 1894. Histoire naturelle des araignées. Deuxième édition, tome premier: 489-760. Roret, Paris.

Simon E. 1929. Les arachnides de France. Synopsis générale et catalogue des espèces françaises de l'ordre des Araneae. Tome VI. $3^{e}$ partie: 533-772. Roret, Paris.

Uliana M. 2018. "In memoria” Harald Hansen. Lavori della Società Veneziana di Scienze Naturali 43: 165.

Wiehle H. 1956. Spinnentiere oder Arachnoidea (Araneae). 28. Familie Linyphiidae-Baldachinspinnen. Die Tierwelt Deutschlands 44: 1-337.

World Spider Catalog 2020. World Spider Catalog. Natural History Museum Bern.

Available from http://wsc.nmbe.ch, ver. 21.0 [accessed 14 Feb. 2020]. https://doi.org/10.24436/2

Manuscript received: 5 January 2020

Manuscript accepted: 24 March 2020

Published on: 5 June 2020

Topic editor: Rudy C.A.M. Jocqué

Desk editor: Kristiaan Hoedemakers 
Printed versions of all papers are also deposited in the libraries of the institutes that are members of the EJT consortium: Muséum national d'histoire naturelle, Paris, France; Meise Botanic Garden, Belgium; Royal Museum for Central Africa, Tervuren, Belgium; Royal Belgian Institute of Natural Sciences, Brussels, Belgium; Natural History Museum of Denmark, Copenhagen, Denmark; Naturalis Biodiversity Center, Leiden, the Netherlands; Museo Nacional de Ciencias Naturales-CSIC, Madrid, Spain; Real Jardín Botánico de Madrid CSIC, Spain; Zoological Research Museum Alexander Koenig, Bonn, Germany; National Museum, Prague, Czech Republic. 